\title{
Chromogenic Nitrophenolate-based Substrates for Light- Driven Hybrid P450 BM3 Enzyme Assay
}

Quan Lam, Alejandro Cortez, Thanh Truc Nguyen, Mallory Kato, ${ }^{*}$ Lionel Cheruzel*

San José State University, Department of Chemistry, One Washington Square, San José, CA 95192-0101

${ }^{*}$ Corresponding authors.

Address: San José State University

Department of Chemistry

One Washington Square

San José, CA 95192-0101

Tel: +1 4089245283; Fax: +1 4089244945;

E-mail address: lionel.cheruzel@sjsu.edu (L. Cheruzel);

mallory.kato@gmail.com (M. Kato) 


\section{Graphical Abstract}
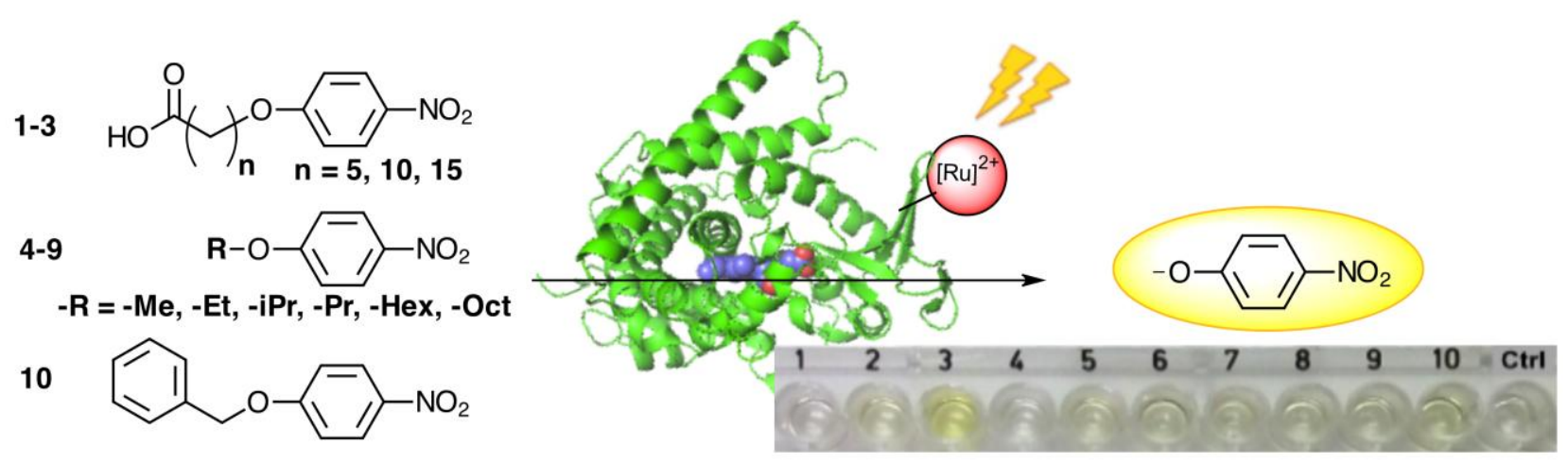

\section{Synopsis}

A family of p-nitrophenoxy derivatives was investigated as useful chromogenic substrates compatible with the light-driven hybrid P450 BM3 enzymes. The validation of this assay and its adaptability to a 96-well plate format will enable the screening of the next generation of hybrid enzymes with photocatalytic activity towards non-natural substrates.

\section{$\underline{\text { Keywords }}$}

light-driven biocatalysis, hybrid P450 BM3 enzymes, colorimetric assay, p-nitrophenoxy derivatives, chromogenic substrates. 


\section{Abstract}

The incorporation of a p-nitrophenoxy moiety in substrates has enabled the development of colorimetric assays to rapidly screen for O-demethylation activity of P450 enzymes. For the light-driven hybrid P450 BM3 enzymes, where a Ru(II) photosensitizer powers the enzyme upon visible light irradiation, we have investigated a family of p-nitrophenoxy derivatives as useful chromogenic substrates compatible with the light-driven approach. The validation of this assay and its adaptability to a 96-well plate format will enable the screening of the next generation of hybrid P450 BM3 enzymes towards $\mathrm{C}-\mathrm{H}$ bond functionalization of non-natural substrates. 


\section{Introduction}

Colorimetric and fluorimetric assays have enabled high-throughput screening of enzyme activity and the improvement of biocatalysis.[1,2] These assays rely on the enzyme attacking substrate bonds of interest to produce easily detectable phenomenon such as color or fluorescence intensity changes. In one such colorimetric assay, the pnitrophenoxy moiety is incorporated into various substrates enabling the release of an intense yellow p-nitrophenolate chromophore upon enzyme activation. For example, several $p$-nitrophenol ethers and esters have been synthesized for phosphatase,[3] esterase $[4,5]$ and $\beta$-galactosidase[6] enzymatic activity studies. For cytochrome P450 heme thiolate enzymes, which perform selective $\mathrm{C}-\mathrm{H}$ bond functionalization,[7] several 4-nitrophenoxy derivatives have been used to probe the P450 O-demethylation activity.[8-10] Hydroxylation of the carbon bearing the nitrophenoxy moiety yields an unstable hemiacetal, which dissociates spontaneously to release p-nitrophenolate with a strong absorbance at $400 \mathrm{~nm}$ (See Scheme 1).<smiles>[2H]COc1ccc([N+](=O)[O-])cc1</smiles>

Scheme 1: Specific C-H hydroxylation of p-nitrophenoxy substrates by P450 enzymes leading to the formation of a yellow p-nitrophenolate chromophore via an unstable hemiacetal intermediate.

Early on, 4-nitroanisole,[8] 4-nitrophenetole[9] and 1-isopropoxy-4-nitrobenzene[10] were established as useful substrates to assess microsomal P450 enzyme activity. For the highly active long chain fatty acid hydroxylase, P450 BM3,[11] Schwaneberg and 
coworkers initially developed a class of natural substrate mimics, $p$ nitrophenoxycarboxylic acids $(\mathrm{pNCA})$, which would release $\mathrm{p}$-nitrophenolate after selective $\mathrm{C}-\mathrm{H}$ bond functionalization at the terminal carbon of the long fatty acid chain.[12] Meanwhile, the Arnold group utilized a 1-octyl-4-nitrophenoxy compound to identify mutants capable of alkane hydroxylation.[13, 14]

The pNCA and 1-octyl-4-nitrophenoxy derivatives have since been widely exploited in the evolution of P450 BM3 mutants as powerful biocatalysts. Hydroxylation of nonnatural substrates ranging from small alkane chains, to heterocyclic and polycyclic aromatic compounds as well as raw materials, has then been achieved.[15-17] The pNCA assay was first used to identify rationally evolved variants with enhanced activity towards shorter chain $(\mathrm{C} 8-\mathrm{C} 10)$ fatty acids.[18, 19] It was subsequently shown that mutants from such library screens were also highly active toward non-natural substrates such as heterocycles and polycyclic aromatic compounds that were poorly accepted by wild type P450 BM3 enzyme.[20] The screen was also successfully used to increase the catalytic efficiency of an artificial electron donor system (Co(III) sepulchrate/Zn dust) to power P450 BM3 mutants.[21, 22]

Our research group has been developing hybrid P450 enzymes that utilize a covalently attached $\mathrm{Ru}(\mathrm{II})$-photosensitizer to drive P450 reactions upon visible light excitation.[23, 24] Recently, high photocatalytic activity has been achieved in the selective hydroxylation of fatty acids such as lauric or 10 -undecenoic acids.[25, 26] In the pursuit of non-natural substrate functionalization using hybrid P450 BM3 mutants, we have been interested in developing colorimetric assays compatible with the light-driven 
process (See Fig. 1). Herein, we report on a series of p-nitrophenoxy chromogenic substrates (1-10) investigated as candidates for light-driven screening assays.

$1-3$

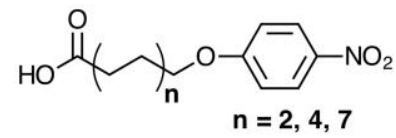

4-9

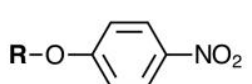

$\mathrm{R}=\mathrm{Me}$, Et, iPr, Pr, Hex, Oct

10
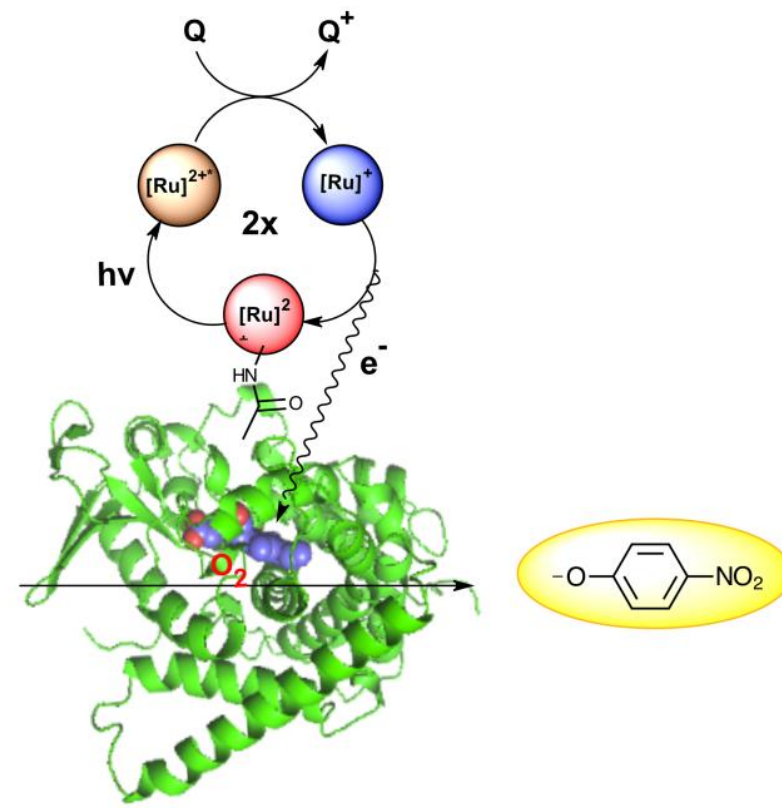

Fig. 1: Series of p-nitrophenoxy derivatives (1-10) investigated as chromogenic substrates for the light-driven hybrid enzymes containing a $R u(I I)$-diimine photosensitizer covalently attached to the P450 BM3 heme domain enzyme. Upon light excitation, the $R u(I I)^{\star}$ excited state is quenched by a soluble molecule $(Q)$ generating a highly reductive species $\left([\mathrm{Ru}]^{+}\right)$capable of delivering electrons to the active site and sustain photocatalytic activity.

The p-nitrophenoxy derivatives comprise fatty acid analogues, pNCAs, of various chain lengths (1-3) as well as alkoxy (4-9) and benzoxy (10) derivatives of 4-nitrobenzene (See Fig. 1). These compounds were aimed at mimicking relevant features of nonnatural substrates of interest in the screening of new hybrid P450 BM3 mutants. All the studied compounds were compatible with the light-driven conditions as negligible 
background activity in the control reactions was observed. The photocatalytic activity ranges from low turnover numbers with the alkoxy derivatives (4-9) to moderate activity with the benzoxy (10) and high activity with the long chain fatty acid (3). Using substrate 3, we were able to optimize the reaction conditions and found the assay to be sensitive enough to distinguish between hybrid enzyme mutants and photosensitizers. The kinetic parameters for the enzyme photocatalytic activity were determined for both substrates 3 and 10. Furthermore, conversion to a 96-well plate format generated comparable product yields, thereby increasing the overall throughput for the assay.

\section{Methods}

\subsection{Hybrid P450 BM3 enzymes}

The hybrid enzymes (tK97C-1, sL407C-1 and sL407C-2) used in this study were generated as previously reported.[25, 26] The tK97C-1 corresponds to a triply mutated P450 BM3 heme domain (C62A, C156S and K97C) labeled with a Ru(bpy) ${ }_{2}$ PhenA (1) photosensitizer (bpy $=2,2^{\prime}$-bipyridine and PhenA $=5$-iodoacetamido-1,10phenanthroline). The sL407C-2 corresponds to a singly mutated P450 BM3 heme domain (L407C) labeled with a $\mathrm{Ru}\left((\mathrm{OMe})_{2} \mathrm{bpy}\right)_{2}$ PhenA photosensitizer (2) ((OMe) $)_{2}$ bpy $=4,4^{\prime}$-dimethoxy-2,2'-bipyridine). Purified proteins with $R z$ ratio of 1.8 were labeled with the corresponding $\mathrm{Ru}(\mathrm{II})$ photosensitizers (1 and 2) and the covalent attachment was confirmed using techniques previously established such as UV-vis and fluorescence spectroscopy as well as mass spectrometry.[23, 24, 26] 
2.2 Synthesis of chromogenic substrates (1-10)

All analytical grade reagents, including 4-nitroanisole (4), were purchased from Fisher and used without further purification. ${ }^{1} \mathrm{H}$ and ${ }^{13} \mathrm{C}$ NMR spectra were recorded at $25{ }^{\circ} \mathrm{C}$ on a Varian $400 \mathrm{MHz}$ instrument. UV-visible (UV-vis) spectra were recorded on a Cary 60 UV-vis spectrophotometer. The substrates (1-3 and 5-10) were synthesized following reported procedures[12,13] with slight modifications as follows:

2.2.1 Synthesis of the p-nitrophenoxy fatty acids (6-,11- and 16-pNCA, 1-3):

The bromo methyl or ethyl esters of the corresponding fatty acids with various chain lengths (C6 (500 mg, $2.3 \mathrm{mmol})$, C11 (500 mg, $1.7 \mathrm{mmol})$ and C16 (500 mg, 1.43 $\mathrm{mmol}))$ and p-nitrophenol ((369 mg, $2.44 \mathrm{mmol}),(258 \mathrm{mg}, 1.86 \mathrm{mmol})$ and $(217 \mathrm{mg}$, $1.56 \mathrm{mmol})$, respectively) were dissolved in DMSO $(8 \mathrm{~mL})$ with potassium carbonate ((367 mg, $2.65 \mathrm{mmol}),(256 \mathrm{mg}, 1.86 \mathrm{mmol}),(215 \mathrm{mg}, 1.56 \mathrm{mmol})$ respectively). The reaction was allowed to proceed for 4 hours at $120{ }^{\circ} \mathrm{C}$ and then cooled to room temperature. The desired product was precipitated with the addition of water. The powder is then vacuum filtered and dried. Saponification of the esters was achieved by adding $1 \mathrm{M} \mathrm{NaOH}$ to an acetone solution (20 mL, 50:50) containing the desired $\mathrm{p}$ nitrophenolate esters. After 24 hours, the acetone was removed and the product was precipitated by dropwise addition of $1 \mathrm{M} \mathrm{HCl}$ to reach $\mathrm{pH}$ below 3.0. The desired product was collected by vacuum filtration and recrystallized in DMSO/water mixture (C6 (406 mg, 77\%), C11 (340 mg, 62\%), C16 (416 mg, 74\%)). The ${ }^{1} \mathrm{H}$ and ${ }^{13} \mathrm{C}$ NMR chemical shifts for 6- and 11-pNCA match the previously reported values (See Fig. S7S9).[12] 
p-nitrophenoxyhexadecanoic acid (16-pNCA, 3): $\mathrm{mp}=105-107^{\circ} \mathrm{C} ;{ }^{1} \mathrm{H}$ NMR $\left(\mathrm{CDCl}_{3}\right): \delta$ $=8.15 \mathrm{ppm}\left(\mathrm{d}, 2 \mathrm{H}, \mathrm{NO}_{2}\right.$-phenyl-), $6.91 \mathrm{ppm}(\mathrm{d}, 2 \mathrm{H}$, phenyl-O-), $4.03 \mathrm{ppm}(\mathrm{t}, 2 \mathrm{H}$, phenylO- $\left.\mathrm{CH}_{2}{ }^{-}\right), 2.32 \mathrm{ppm}\left(\mathrm{t}, 2 \mathrm{H},-\underline{\mathrm{CH}}_{2}-\mathrm{COO}\right), 1.78 \mathrm{ppm}\left(\mathrm{m}, 2 \mathrm{H},-\mathrm{O}-\mathrm{CH}_{2}-\underline{\mathrm{CH}}_{2}{ }^{-}\right), 1.58 \mathrm{ppm}(\mathrm{m}$, $2 \mathrm{H},-\underline{\mathrm{CH}_{2}}-\mathrm{CH}_{2}-\mathrm{COO}$ ), $1.41 \mathrm{ppm}(\mathrm{m}, 2 \mathrm{H}), 1.25 \mathrm{ppm}(\mathrm{m}, 2 \mathrm{H}) ;{ }^{13} \mathrm{C} \mathrm{NMR}: \delta=180.0 \mathrm{ppm}$

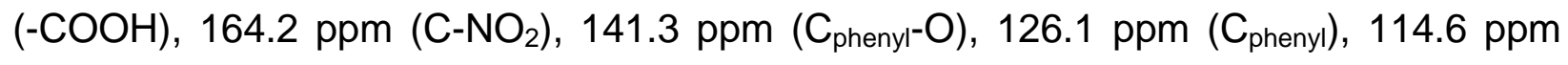
( $\left.\mathrm{C}_{\text {phenyl) }}\right), 69.1$ ppm (-O- $\left.\mathrm{CH}_{2}-\right), 40.6$ ppm (- $\left.\mathrm{CH}_{2}-\right), 34.0$ ppm (- $\left.\mathrm{CH}_{2}-\mathrm{COOH}\right), 29.1-29.8$ ppm $\left(-\mathrm{CH}_{2}^{-}\right), 26.1 \mathrm{ppm}\left(-\mathrm{CH}_{2}^{-}\right), 24.9\left(-\mathrm{CH}_{2}^{-}\right)$.

2.2.2 Synthesis of the 1-alkoxy-4-nitrobenzene (5-9):

A DMSO solution $(20 \mathrm{~mL})$ of the corresponding bromoalkyl compounds (1.1 eq.) was added to a solution $(20 \mathrm{~mL})$ containing $\mathrm{p}$-nitrophenolate $(1$ eq.) and potassium carbonate (1 eq.). The reaction mixture was stirred at $70{ }^{\circ} \mathrm{C}$ for 4 to 6 hours. Upon cooling and addition of water $(50 \mathrm{~mL})$, the aqueous solution was extracted three times with dichloromethane. The desired products were recovered after evaporation of the organic layer. For $\mathbf{5}$, white crystalline material was obtained after recrystallization in DMSO/water (65\%). For 6-9, the desired compound was recovered as a clear oil (60$85 \%)$ after purification by flash column chromatography using silica and petroleum/ether (8:2) as eluent.

1-ethyl-4-nitrobenzene (5): $\mathrm{mp}=58-61^{\circ} \mathrm{C} .{ }^{1} \mathrm{H}$ NMR $\left(\mathrm{CDCl}_{3}\right): \delta=8.14 \mathrm{ppm}(\mathrm{d}, 2 \mathrm{H}$, $\mathrm{NO}_{2}$-phenyl-), 6.88 ppm (d, 2H, phenyl-O-), 4.08 ppm (q, 2H), $1.42 \mathrm{ppm}(\mathrm{t}, 3 \mathrm{H}) ;{ }^{13} \mathrm{C}$

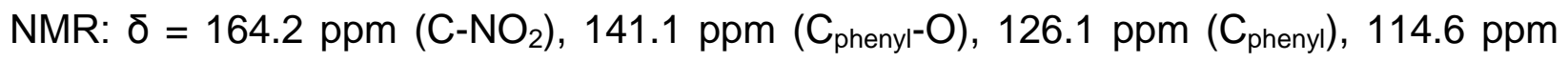
( $\left.\mathrm{C}_{\text {phenyl }}\right), 64.6 \mathrm{ppm}\left(-\mathrm{O}-\mathrm{CH}_{2}-\right), 14.7 \mathrm{ppm}\left(-\mathrm{CH}_{3}\right)$. 
1-isopropyl-4-nitrobenzene (6): ${ }^{1} \mathrm{H}$ NMR $\left(\mathrm{CDCl}_{3}\right): \delta=8.04$ ppm (d, $2 \mathrm{H}, \mathrm{NO}_{2}$-phenyl-), 6.83 ppm (d, 2H, phenyl-O-), 4.56 ppm (m, 1H), 1.29 ppm (d, 6H); ${ }^{13} \mathrm{C}$ NMR: $\delta=163.4$ ppm (C-NO $\left.{ }_{2}\right), 141.0$ ppm ( $\left.\mathrm{C}_{\text {phenyl-O}} \mathrm{O}\right), 126.0$ ppm ( $\left.\mathrm{C}_{\text {phenyl }}\right), 115.3$ ppm $\left(\mathrm{C}_{\text {phenyl }}\right), 71.1 \mathrm{ppm}$ (-O-CH-), 21.9 ppm (- $\left.\mathrm{CH}_{3}\right)$.

1-propyl-4-nitrobenzene (7): ${ }^{1} \mathrm{H}$ NMR $\left(\mathrm{CDCl}_{3}\right): \delta=8.14 \mathrm{ppm}\left(\mathrm{d}, 2 \mathrm{H}, \mathrm{NO}_{2}\right.$-phenyl-), 6.91 ppm (d, 2H, phenyl-O-), 3.99 ppm (q, 2H), $1.81 \mathrm{ppm}(\mathrm{m}, 2 \mathrm{H}), 1.02 \mathrm{ppm}(\mathrm{t}, 3 \mathrm{H}) ;{ }^{13} \mathrm{C}$ NMR: ${ }^{13} \mathrm{C}$ NMR: $\delta=164.4$ ppm $\left(\mathrm{C}-\mathrm{NO}_{2}\right), 141.3$ ppm ( $\mathrm{C}_{\text {phenyl-O }}$ ), 125.9 ppm $\left(\mathrm{C}_{\text {phenyl }}\right)$, 114.5 ppm ( $\left.\mathrm{C}_{\text {phenyl }}\right), 70.4$ ppm (-O- $\left.\mathrm{CH}_{2^{-}}\right), 22.4$ ppm (- $\left.\mathrm{CH}_{2^{-}}\right), 10.5 \mathrm{ppm}\left(-\mathrm{CH}_{3}\right)$.

1-hexyl-4-nitrobenzene (8): ${ }^{1} \mathrm{H}$ NMR $\left(\mathrm{CDCl}_{3}\right): \delta=8.11$ ppm (d, $2 \mathrm{H}, \mathrm{NO}_{2}$-phenyl-), 6.88 ppm (d, 2H, phenyl-O-), 3.98 ppm (t, 2H), 1.75 ppm (t, 2H), 1.39 ppm (t, 2H), 1.27 ppm $(\mathrm{t}, 4 \mathrm{H}), 0.84 \mathrm{ppm}(\mathrm{t}, 3 \mathrm{H}) ;{ }^{13} \mathrm{C}$ NMR: $\delta=164.4 \mathrm{ppm}\left(\mathrm{C}-\mathrm{NO}_{2}\right), 141.4 \mathrm{ppm}\left(\mathrm{C}_{\text {phenyl}} \mathrm{O}\right)$, 126.0 ppm ( $\left.\mathrm{C}_{\text {phenyl }}\right), 114.5$ ppm ( $\left.\mathrm{C}_{\text {phenyl }}\right), 69.1$ ppm (-O- $\left.\mathrm{CH}_{2^{-}}\right), 31.6$ ppm (- $\left.\mathrm{CH}_{2^{-}}\right), 29.1$ ppm (- $\left.\mathrm{CH}_{2}^{-}\right), 25.7$ ppm (- $\left.\mathrm{CH}_{2}^{-}\right), 22.7$ ppm (- $\left.\mathrm{CH}_{2}^{-}\right), 14.1 \mathrm{ppm}\left(-\mathrm{CH}_{3}\right)$.

1-octyl-4-nitrobenzene (9): ${ }^{1} \mathrm{H}$ NMR $\left(\mathrm{CDCl}_{3}\right): \delta=8.11 \mathrm{ppm}\left(\mathrm{d}, 2 \mathrm{H}, \mathrm{NO}_{2}\right.$-phenyl-), 6.88 ppm (d, 2H, phenyl-O-), 3.98 ppm (t, 2H), 1.75 ppm (t, 2H), 1.39 ppm (t, 2H), 1.22 ppm (t, 8H), 0.82 ppm (t, 3H); ${ }^{13} \mathrm{C}$ NMR: $\delta=164.4$ ppm $\left(\mathrm{C}^{-N^{2}}{ }_{2}\right), 141.4$ ppm $\left(\mathrm{C}_{\text {phenyl-O }} \mathrm{O}\right)$, 126.0 ppm ( $\left.\mathrm{C}_{\text {phenyl }}\right), 114.5$ ppm $\left(\mathrm{C}_{\text {phenyl }}\right), 69.0$ ppm (-O- $\left.\mathrm{CH}_{2^{-}}\right), 31.9 \mathrm{ppm}\left(-\mathrm{CH}_{2^{-}}\right), 29.1$ ppm (- $\left.\mathrm{CH}_{2}^{-}\right), 26.1$ ppm (- $\left.\mathrm{CH}_{2}^{-}\right), 22.8$ ppm (- $\left.\mathrm{CH}_{2^{-}}\right), 14.2 \mathrm{ppm}\left(-\mathrm{CH}_{3}\right)$. 
2.2.3 Synthesis of 1-benzoxy-4-nitrobenzene (10):

A DMSO solution $(20 \mathrm{~mL})$ of benzyl bromide (1.2 eq) was added to a DMSO solution $(20 \mathrm{~mL})$ containing p-nitrophenolate (1 eq.) and potassium carbonate (1 eq.). The reaction mixture was then stirred at $120^{\circ} \mathrm{C}$ for $4 \mathrm{~h}$. Upon cooling, the desired product was precipitated from the solution by addition of water and collected by vacuum filtration. White crystalline material was obtained after recrystallization from DMSO/water (75\% yield).

1-benzoxy-4-nitrobenzene (10): $\mathrm{mp}=112-11{ }^{\circ} \mathrm{C} .{ }^{1} \mathrm{H} \mathrm{NMR}\left(\mathrm{CDCl}_{3}\right): \delta=8.16 \mathrm{ppm}(\mathrm{d}$, $2 \mathrm{H}, \mathrm{NO}_{2}$-phenyl-), 7.40 ppm (d, 4H, benzyl), 7.34 ppm (s, $1 \mathrm{H}$, benzyl), 6.94 ppm (d, 2H, phenyl-O-), 5.13 ppm (q, 2H); ${ }^{13} \mathrm{C}$ NMR: $\delta=163.8$ ppm (C-NO $), 141.8$ ppm ( $\mathrm{C}_{\text {phenyl-O}}$ ), 135.6 ppm ( $\left.C_{\text {benzyl }}\right), 129.0$ ppm ( $\left.C_{\text {benzyl }}\right), 128.7$ ppm ( $\left.C_{\text {benzyl }}\right), 127.7$ ppm $\left(C_{\text {benzyl }}\right), 126.1$ ppm ( $\left.\mathrm{C}_{\text {phenyl }}\right), 115.0$ ppm ( $\left.\mathrm{C}_{\text {phenyl }}\right), 70.9$ ppm (-O- $\left.\mathrm{CH}_{2}-\right)$.

\subsection{Photocatalytic reactions and optimization of the conditions}

Photocatalytic reactions are typically run as follows: $1 \mu \mathrm{M}$ of enzyme with $100 \mathrm{mM}$ diethyldithiocarbamate and $400 \mu \mathrm{M}$ of substrates in a $500 \mu \mathrm{L}$ total reaction volume. The solution, maintained at $30^{\circ} \mathrm{C}$ in a water bath, is then irradiated for 30 min before being quenched by the addition of $10 \mu \mathrm{L}$ of $6 \mathrm{M} \mathrm{NaOH}$. For the optimization of the reaction conditions, individual parameters in the light-driven process were varied one at a time including the nature and concentration $(0 \mathrm{mM}$ to $150 \mathrm{mM})$ of reductive quencher, reaction $\mathrm{pH}(7.0$ to 9.0$)$, temperature $\left(10^{\circ} \mathrm{C}\right.$ to $\left.35^{\circ} \mathrm{C}\right)$, buffer concentration $(10 \mathrm{mM}$ to $100 \mathrm{mM}$ ), and light intensity. 


\subsection{Control reactions}

Two sets of control reactions were performed to ensure that the observed color in the assay is not generated from background reactions or through the hydrogen peroxide shunt. The first set involved the systematic removal of individual components necessary for the light-driven process (i.e. reductive quencher, photosensitizer covalent attachment, hybrid enzyme). The second set uses peroxide shunt reactions with $10 \mathrm{mM}$ hydrogen peroxide.

\subsection{Substrate binding determination}

The dissociation constants, $\mathrm{K}_{\mathrm{d}}$, were determined by optical titration with DMSO solutions of the respective substrates, keeping the maximum concentration of DMSO below $2.5 \%$ (v/v). All hybrid enzyme solutions were at $2 \mu \mathrm{M}$ in $50 \mathrm{mM}$ Tris at $\mathrm{pH} 8.5$ and room temperature. The difference spectra between 350 and $650 \mathrm{~nm}$ were recorded $30 \mathrm{~s}$ after each addition, using the substrate-free hybrid enzyme solution as the reference spectrum. For the substrates displaying binding, the peak-to-trough difference between 390 and $420 \mathrm{~nm}$ was plotted against substrate concentrations (See Fig. S1). Substrate dissociation constants were extracted from fitting the data of triplicate experiments to a rectangular hyperbolic function of the type $Y=B \max ^{*} X /(K d+X)$ for specific substrate binding using the GraphPad Prism ${ }^{\circledR}$ software. 


\subsection{Enzyme kinetic parameters}

Kinetics of the hybrid mutants were measured by monitoring the product formation at $410 \mathrm{~nm}$ (extinction coefficient $=13,200 \mathrm{M}^{-1} \mathrm{~cm}^{-1}$ ). [3] The substrate concentrations are set from $5 \mu \mathrm{M}$ to $700 \mu \mathrm{M}$ with either $2 \mu \mathrm{M}$ of tK97C-1 or $1 \mu \mathrm{M}$ of the sL407C hybrid enzymes. Each reaction, with a total reaction volume of $500 \mu \mathrm{L}$ containing substrate, hybrid enzyme, and $100 \mathrm{mM}$ DTC in $50 \mathrm{mM}$ tris $\mathrm{pH}$ 8.2, is irradiated with visible light (IR and UV-cutoff filters) from an Orion $1000 \mathrm{~W}$ Xenon arc lamp and stopped using $5 \mu \mathrm{L}$ of $6 \mathrm{M} \mathrm{NaOH}$ after 1 minute to eliminate overlapping absorbance from the hybrid enzymes.

\subsection{6-well plate assay}

Each well, with a total reaction volume of $200 \mu \mathrm{L}$, contains $1 \mu \mathrm{M}$ enzyme, $400 \mu \mathrm{M}$ substrate and $100 \mathrm{mM} \mathrm{DTC}$ in $50 \mathrm{mM}$ tris $\mathrm{pH}$ 8.2. The plate is then irradiated using LED lamps (Apollo horticulture $100 \times 3 \mathrm{~W}$ ). After 30 minutes of reaction, $10 \mu \mathrm{L}$ of $6 \mathrm{M} \mathrm{NaOH}$ is added to each well to stop the reaction. After spinning and transferring the reaction mixture to a new plate, the absorbance at $405 \mathrm{~nm}$ is read using a Vmax microplate reader (Molecular Devices).

\section{Results}

\subsection{Substrate binding to $\mathrm{P} 450 \mathrm{BM} 3$ hybrid mutants.}

Binding of type-I ligands to the P450 heme domains induces the characteristic ferric spin shift upon displacement of the coordinated water ligand. This is accompanied with the appearance of a peak at $390 \mathrm{~nm}$ and a trough at $420 \mathrm{~nm}$. In this study, a rise at 390 $\mathrm{nm}$ was only observed with compounds 2 and $\mathbf{3}$. The peak-to-trough separations in the 
difference spectra binding titration curves are typical of single site reversible binding of substrate and were fitted using a rectangular hyperbolic function (See Methods Section 2.5 and Fig. S1). The determined binding constant values for substrates 2 and $\mathbf{3}$ with sL407C-1 are 26 and $7 \mu \mathrm{M}$, respectively. We previously showed that the covalent attachment of the $R u(I I)$ photosensitizer does not affect the binding of substrates to the heme domain as the photosensitizer is attached at the proximal side of the heme.[23]

3.2 Screening of the various substrates with the light-driven approach.

We investigated the development of the yellow p-nitrophenolate chromophore with the chromogenic substrates (1-10) under the flash quench reductive conditions using the sL407C-1 hybrid enzyme and diethyldithiocarbamate (DTC) as reductive quencher. Yellow color associated with product formation was detected with most chromogenic substrates while negligible activity was observed in the control reactions (See Fig. 2 and Fig. S6). The total turnover numbers (TTN) obtained for the substrates after 30 minutes of visible light irradiation are presented in Figure 2. For the pNCA substrates (1-3), chain length dependence is observed in the colorimetric assay in good agreement with results obtained with the holoenzyme[12]. The highest TTN of 120 is obtained with the 16-pNCA substrate (3).

In the alkoxy substituent series (4-9), minimal activities are observed with TTN ranging from 12 to 24 . Preference is noted for the propoxy derivative (7) with noticeable activity $($ TTN $=24)$. The assay can also distinguish between branched and linear $\mathrm{C}_{3}$ substitutents (6 vs. 7). Interestingly, introduction of a benzyl moiety in substrate (10) leads to an enhanced activity compared to the alkoxy derivatives $($ TTN $=40)$. 


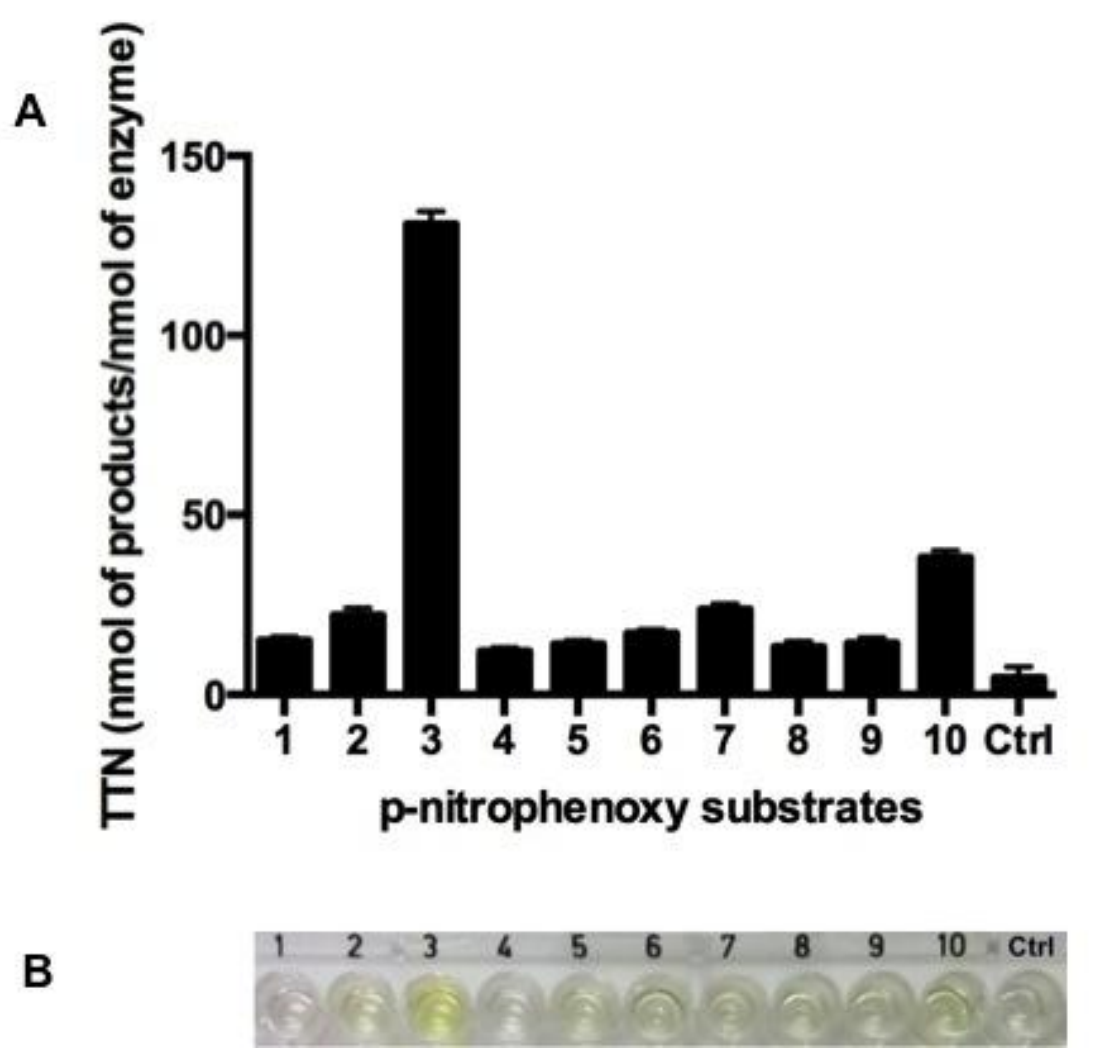

Fig. 2. Graphical representation of the sL407C-1 photocatalytic activity towards $p$ nitrophenoxy substrates (1-10) in typical flash quench reductive conditions $(A)$ and in 96-well plate format (B).

\subsection{Assay validation and optimization of the reaction conditions}

In a series of control reactions, removal of individual components of the light driven approach such as the absence of quencher, P450 BM3 heme domain, visible light or non-covalently attached photosensitizer leads to minimal product formation confirming the validity of the assay with the light-driven approach (See Fig. 2). Meanwhile, reactions run under the peroxide shunt (hydrogen peroxide, $10 \mathrm{mM}$ ) shows less than $1 \%$ product formation. This is consistent with the limited peroxygenase activity of the wild-type P450 enzyme $[27,28]$ and with our own finding that the high photocatalytic 
activity in the hybrid enzyme is indicative of the $R u(I I)$ photosensitizer being able to deliver the necessary electrons to the heme domain.[24, 26]

The ease of the colorimetric assay has also allowed for the screening of optimal reaction conditions. Hence, several parameters were investigated such as the nature and concentration of the reductive quenchers, $\mathrm{pH}$, buffer concentration, temperature and light intensity (See Fig. S2). A variety of commonly known reductive quenchers was tested including the $N, N, N^{\prime}, N^{\prime}$-tetramethyl-p-phenylenediamine, ethylenediaminetetraacetic acid, ascorbic acid, triethylamine, and bis-catechol borate.[29] None of the investigated reductive quenchers led to significant activity compared to the diethyldithiocarbamate (DTC) quencher used.[30] As shown previously, DTC possesses unique properties that renders it a suitable quencher for the light-driven photocatalysis: It is highly water soluble and irreversibly quenches the $\mathrm{Ru}(\mathrm{II})^{*}$ excited state. Moreover, it is compatible with the aerobic conditions and the P450 reaction as it does not interfere with substrate binding. Varying the DTC concentration did lead to change in activity as expected and confirmed that the original DTC concentration of $100 \mathrm{mM}$ was optimal for activity. A decrease in $\mathrm{pH}$ to 7.0 compared to the current value of 8.2 leads to $50 \%$ decrease in activity consistent with a reported optimal basic $\mathrm{pH}$ for the holoenzyme.[11] Meanwhile, lowering the buffer concentration to $10 \mathrm{mM}$ led to a $30 \%$ increase in activity. Finally, a temperature dependence was observed for the rate of product formation (See Fig. S2) with an optimal temperature for the colorimetric assay of $30^{\circ} \mathrm{C}$. From the Arrhenius plot (See Fig. S3), an activation energy of $6.7 \mathrm{kcal} / \mathrm{mol}$ was found for the light-driven hydroxylation of substrate 3 by the hybrid SL407C-1 enzyme. 


\subsection{Enzyme Kinetics}

The colorimetric assay has also facilitated the determination of the kinetic parameters for the hybrid P450 BM3 photocatalytic hydroxylation reactions. Initial reaction rates were determined after $1 \mathrm{~min}$ of light exposure at various substrate concentrations (See Fig. S4-5). The assay proved sensitive enough to differentiate between various mutants (sL407C vs. tK97C) and photosensitizers (1 and 2) as shown in Table 1. A high $\mathrm{k}_{\text {cat }}$ value of $36 \mathrm{eq} / \mathrm{min}$ was obtained with the sL407C-1 hybrid enzyme in the hydroxylation of substrate 3, a 4-fold increase compared to the $\mathrm{k}_{\text {cat }}$ value obtained for $\mathrm{tK97C-1.} \mathrm{A} \mathrm{k}_{\text {cat }}$ value of $16.6 \mathrm{eq} / \mathrm{min}$ was found for the hydroxylation of substrate 10 by the sL407C-1. As noted previously[26], a $15 \%$ increase in rate is observed with the sL407C-2 hybrid enzyme with electron donating groups on the ancillary bipyridine ligands of the photosensitizer.

\begin{tabular}{|c|c|c|c|c|}
\hline & \multicolumn{3}{|c|}{ Substrate 3 } & Substrate 10 \\
\cline { 2 - 5 } & tK97C-1 & sL407C-1 & sL407C-2 & sL407C-1 \\
\hline $\mathrm{K}_{\mathrm{m}}(\mathrm{uM})$ & $30.0 \pm 1.9$ & $11.1 \pm 0.6$ & $12.3 \pm 0.9$ & $23.9 \pm 2.2$ \\
\hline $\mathrm{k}_{\text {cat }}(\mathrm{eq} / \mathrm{min})$ & $8.4 \pm 0.5$ & $36.2 \pm 0.6$ & $42.1 \pm 0.7$ & $11.8 \pm 0.3$ \\
\hline
\end{tabular}

Table 1: Kinetic parameters for the hybrid enzymes in the hydroxylation of substrates 3 and 10. 


\section{Discussion}

Considerable efforts are dedicated to the discovery and optimization of enzymes as relevant biocatalysts to meet industrial challenges.[31, 32] High-throughput screening of enzyme activity and optimal reaction conditions are typically facilitated by the development of validated assays.[2] Building upon our results with $\mathrm{Ru}(\mathrm{II})$ photosensitized hybrid P450 enzymes capable of high photocatalytic activity,[25, 26] we sought to develop colorimetric assays compatible with the light-driven approach to streamline the screening process for activity toward non-natural substrates. Following the work by Schwaneberg and others, $[12,13,19]$ we investigated a series of $p$ nitrophenoxy derivatives (1-10) as chromogenic substrates for hybrid P450 BM3 enzymes. Despite substrates $\mathbf{2}$ and $\mathbf{3}$ only yielding noticeable high-spin conversion, photocatalytic activity is detected with most substrates while negligible background is found in all the control reactions. The light-driven approach is also applicable to 96 -well plate format, indicating that the results obtained in the preparative scale are translatable to a screening format (See Fig. 2).

For the fatty acid mimics (1-3), chain length dependence is observed in the light-driven approach with the highest activity observed on the 16-pNCA substrate (3). The observed photocatalytic activity established the assay to be sensitive enough to distinguish between the nature and position of the photosensitizers as well as to determine the kinetic parameters for several hybrid enzymes. A $k_{\text {cat }}$ of $42 \mathrm{nmol}$ of product / nmol of enzyme / min was found for the most active sL407C-2 mutant, which is only one-sixth of the $k_{\text {cat }}$ value recorded for the holoenzyme.[12] The electron 
donating groups on the ancillary bipyridine ligands in photosensitizer 2 resulted in a $15 \%$ increase in activity compared with photosensitizer $1 .[26]$

In order to facilitate the screening for non-natural substrates, we expanded the scope of nitrophenoxy compounds to include alkoxy (4-9) derivatives with short and long chains as well as a benzoxy (10) derivative of 4-nitrobenzene. These substrates could easily be synthesized in one-step on gram scale by reacting the respective bromo compounds with p-nitrophenolate in DMSO (See Section 2.2).

Several alkoxy derivatives of 4-nitrobenzene have already been investigated as substrates for P450 enzymes. For example, compounds (4-6) were used with microsomal P450 enzymes[8-10] but show little activity with wild type P450 BM3 enzyme. The Arnold group used 1-octyl-4-nitrophenoxy (9) to support the highthroughput screening of P450 BM3 mutants towards alkane hydroxylation.[13]

Under the flash quench reductive conditions, the sL407C-1 hybrid enzyme shows detectable activities toward the alkoxy derivatives with total turnover numbers ranging from 12 to 24 . A preference is noted for the propoxy compound (7), which is consistent with the activity of wild type P450 BM3 enzyme toward propylbenzene.[33] Along those lines, increased photocatalytic is also observed with the benzoxy compound $\mathbf{1 0}$ with a $\mathrm{k}_{\text {cat }}$ value of $16.6 \mathrm{eq} / \mathrm{min}$ for the sL407C-1 hybrid enzyme.

\section{Conclusion}

The various photocatalytic activities observed with the nitrophenoxy substrates (1-10) is attractive as it opens new avenues in the rapid light-driven screening of various P450 BM3 mutants towards non-natural substrates. The development of the colorimetric 
assay will then streamline and increase the throughput of the screening process in the selection of new hybrid P450 BM3 enzymes.

\section{Abbreviations}

bpy : 2,2'-bipyridine

DMSO : dimethylsulfoxide

sL407C-1 : singly mutated P450 BM3 heme domain labeled with photosensitizer 1.

sL407C-2: singly mutated P450 BM3 heme domain labeled with photosensitizer 2.

tK97C-1: triply mutated P450 BM3 heme domain labeled with photosensitizer 1.

DTC : sodium diethyldithiocarbamate

pNCA : para-nitrophenolate derivatives of long chain fatty acids.

TTN: total turnover numbers measured as nmol of products / nmol of enzyme at the end of the reaction.

WT P450 BM3 : self-sufficient wild type cytochrome P450 enzyme isolated from Bacillus megaterium

\section{Acknowledgements}

The authors gratefully acknowledge financial support by the National Science Foundation through Grant number 1509924. Q.L. would like to thank the McNair program at SJSU (Grant number P217A120295) and the NSF DUE 1258366 for scholarships. 


\section{References}

[1] J.L. Reymond, V.S. Fluxa, N. Maillard, Enzyme assays, Chem Commun, (2009) 34-46.

[2] D. Wahler, J.L. Reymond, High-throughput screening for biocatalysts, Curr Opin Biotech, 12 (2001) 535-544.

[3] M.A. Tabatabai, J.M. Bremner, Use of p-nitrophenyl phosphate for assay of soil phosphatase activity, Soil Biol Biochem, 1 (1969) 301-307.

[4] C. Huggins, J. Lapides, Chromogenic Substrates IV. Acyl Esters of p-Nitrophenol as Substrates for the Colorimetric Determination of Esterase. , J. Biol. Chem., 170 (1947) 467482.

[5] D. Gilham, R. Lehner, Techniques to measure lipase and esterase activity in vitro, Methods, 36 (2005) 139-147.

[6] B.G. Hall, Changes in the Substrate Specificities of an Enzyme during Directed Evolution of New Functions, Biochemistry-Us, 20 (1981) 4042-4049.

[7] I.G. Denisov, T.M. Makris, S.G. Sligar, I. Schlichting, Structure and chemistry of cytochrome P450, Chem Rev, 105 (2005) 2253-2277.

[8] B.C. Jones, C.A. Tyman, D.A. Smith, Identification of the cytochrome P450 isoforms involved in the 0-demethylation of 4-nitroanisole in human liver microsomes, Xenobiotica, 27 (1997) 1025-1037.

[9] S.I. Kuwahara, T. Omura, Different Requirement for Cytochrome-B5 in NadphSupported 0-Deethylation of Para-Nitrophenetole Catalyzed by 2 Types of Microsomal Cytochrome-P-450, Biochem Bioph Res Co, 96 (1980) 1562-1568. 
[10] G.P. Miller, F.P. Guengerich, Binding and oxidation of alkyl 4-nitrophenyl ethers by rabbit cytochrome P450 1A2: Evidence for two binding sites, Biochemistry-Us, 40 (2001) 7262-7272.

[11] C.J.C. Whitehouse, S.G. Bell, L.L. Wong, P450(BM3) (CYP102A1): connecting the dots, Chem Soc Rev, 41 (2012) 1218-1260.

[12] U. Schwaneberg, C. Schmidt-Dannert, J. Schmitt, R.D. Schmid, A continuous spectrophotometric assay for P450 BM-3, a fatty acid hydroxylating enzyme, and its mutant F87A, Anal Biochem, 269 (1999) 359-366.

[13] E.T. Farinas, U. Schwaneberg, A. Glieder, F.H. Arnold, Directed evolution of a cytochrome P450 monooxygenase for alkane oxidation, Adv Synth Catal, 343 (2001) 601606.

[14] A. Glieder, E.T. Farinas, F.H. Arnold, Laboratory evolution of a soluble, self-sufficient, highly active alkane hydroxylase, Nat Biotechnol, 20 (2002) 1135-1139.

[15] R. Fasan, Tuning P450 Enzymes as Oxidation Catalysts, Acs Catal, 2 (2012) 647-666.

[16] S.T. Jung, R. Lauchli, F.H. Arnold, Cytochrome P450: taming a wild type enzyme, Curr Opin Biotech, 22 (2011) 809-817.

[17] V.B. Urlacher, M. Girhard, Cytochrome P450 monooxygenases: an update on perspectives for synthetic application, Trends Biotechnol, 30 (2012) 26-36.

[18] Q.S. Li, U. Schwaneberg, M. Fischer, J. Schmitt, J. Pleiss, S. Lutz-Wahl, R.D. Schmid, Rational evolution of a medium chain-specific cytochrome P-450 BM-3 variant, Bba-Protein Struct M, 1545 (2001) 114-121.

[19] O. Lentz, L.I. Qing-Shang, U. Schwaneberg, S. Lutz-Wahl, P. Fischer, R.D. Schmid, Modification of the fatty acid specificity of cytochrome P450BM-3 from Bacillus 
megaterium by directed evolution: A validated assay, J Mol Catal B-Enzym, 15 (2001) 123133.

[20] D. Appel, S. Lutz-Wahl, P. Fischer, U. Schwaneberg, R.D. Schmid, A P450BM-3 mutant hydroxylates alkanes, cycloalkanes, arenes and heteroarenes, J Biotechnol, 88 (2001) 167171.

[21] J. Nazor, S. Dannenmann, R.O. Adjei, Y.B. Fordjour, I.T. Ghampson, M. Blanusa, D. Roccatano, U. Schwaneberg, Laboratory evolution of P450BM3 for mediated electron transfer yielding an activity-improved and reductase-independent variant, Protein Eng Des Sel, 21 (2008) 29-35.

[22] J. Nazor, U. Schwaneberg, Laboratory evolution of P450BM-3 for mediated electron transfer, Chembiochem, 7 (2006) 638-644.

[23] N.H. Tran, N. Huynh, G. Chavez, A. Nguyen, S. Dwaraknath, T.A. Nguyen, M. Nguyen, L. Cheruzel, A series of hybrid P450 BM3 enzymes with different catalytic activity in the lightinitiated hydroxylation of lauric acid, J Inorg Biochem, 115 (2012) 50-56.

[24] Q. Lam, M. Kato, L. Cheruzel, Ru(II)-diimine functionalized metalloproteins: From electron transfer studies to light-driven biocatalysis, Biochim Biophys Acta Bioenergetics, (2015) In press.

[25] M. Kato, D. Nguyen, M. Gonzalez, A. Cortez, S.E. Mullen, L.E. Cheruzel, Regio- and stereoselective hydroxylation of 10-undecenoic acid with a light-driven P450 BM3 biocatalyst yielding a valuable synthon for natural product synthesis, Bioorgan Med Chem, $22(2014)$ 5687-5691. 
[26] N.H. Tran, D. Nguyen, S. Dwaraknath, S. Mahadevan, G. Chavez, A. Nguyen, T. Dao, S. Mullen, T.A. Nguyen, L.E. Cheruzel, An Efficient Light-Driven P450 BM3 Biocatalyst, J Am Chem Soc, 135 (2013) 14484-14487.

[27] O. Shoji, Y. Watanabe, Peroxygenase reactions catalyzed by cytochromes P450, J Biol Inorg Chem, 19 (2014) 529-539.

[28] P.C. Cirino, F.H. Arnold, A self-sufficient peroxide-driven hydroxylation biocatalyst, Angew Chem Int Edit, 42 (2003) 3299-3301.

[29] K. Kalyanasundaram, Photophysics, Photochemistry and Solar-Energy Conversion with Tris(Bipyridyl)Ruthenium(Ii) and Its Analogs, Coordin Chem Rev, 46 (1982) 159-244.

[30] N.H. Tran, N. Huynh, T. Bui, Y. Nguyen, P. Huynh, M.E. Cooper, L.E. Cheruzel, Lightinitiated hydroxylation of lauric acid using hybrid P450 BM3 enzymes, Chem Commun, 47 (2011) 11936-11938.

[31] T. Davids, M. Schmidt, D. Bottcher, U.T. Bornscheuer, Strategies for the discovery and engineering of enzymes for biocatalysis, Curr Opin Chem Biol, 17 (2013) 215-220.

[32] D.E. Robertson, B.A. Steer, Recent progress in biocatalyst discovery and optimization, Curr Opin Chem Biol, 8 (2004) 141-149.

[33] Q.S. Li, J. Ogawa, R.D. Schmid, S. Shimizu, Residue size at position 87 of cytochrome P450BM-3 determines its stereoselectivity in propylbenzene and 3-chlorostyrene oxidation, Febs Lett, 508 (2001) 249-252. 